\title{
Isolation of Mercury-Resistant Endophytic and Rhizosphere Microorganisms from Grasses in Abandoned Gold Mining Area
}

\author{
Isolasi Mikroorganisme Endofit dan Rhizosfer Resisten \\ Merkuri dari Rumput di Areal Bekas Tambang Emas
}

\author{
Reni Ustiatik $^{1 *}$, Yulia Nuraini ${ }^{2}$, Suharjono ${ }^{3}$, and Eko Handayanto ${ }^{2}$ \\ ${ }^{1}$ Postgraduate Program, Faculty of Agriculture, Universitas Brawijaya \\ Jl. Veteran No. 1 Kota Malang 65145, East Java, Indonesia \\ ${ }^{2}$ Soil Science Department, Faculty of Agriculture, Universitas Brawijaya \\ Jl. Veteran No. 1 Kota Malang 65145, East Java, Indonesia \\ ${ }^{3}$ Department of Biology, Faculty of Science, Universitas Brawijaya \\ Jl. Veteran No. 1 Kota Malang 65145, East Java, Indonesia
}

Received 31 August 2020/Accepted 10 February 2021

\begin{abstract}
There were about 900 hotspots of artisanal and small scale gold mining (ASGM) in Indonesia that recovered gold through amalgamation and cyanidation techniques. Amalgamation technique causes mercury (Hg) pollution to the soil. This study was a preliminary study that aimed to isolate Hg-resistant endophytic and rhizosphere microorganisms from pioneer grasses in the Hg-polluted soil. The most potential microorganism will be used for Hg phytoremediation in the future study. Pioneer grasses were collected from the abandoned gold mining area in Central Lombok Regency, West Nusa Tenggara. Total microorganisms were counted using Colony Forming Unit (CFU) or Standard Plate Count. The microorganism colony was characterized based on morphological characteristics. Hg-resistant endophytic and rhizosphere microorganisms were successfully isolated from pioneer grass (Cynodon dactylon and Eleusine indica) in the study site. The colonies of rhizosphere microorganisms were diverse morphologically compared to endophytic microorganisms based on the number of isolated microorganisms, 20 isolates and 17 isolates, respectively. The density of rhizosphere microorganisms was higher (96\%) than endophytic microorganisms (4\%). The density of rhizosphere bacteria and fungi were $47 \times 10^{3}$ and $2 \times 10^{3} \mathrm{CFU} \mathrm{g}^{-1}$, respectively. However, the density of endophytic bacteria and fungi were only $2 \times 10^{3}$ and $1 \times 10^{3} \mathrm{CFU} \mathrm{g}^{-1}$, respectively.
\end{abstract}

Keywords: endophytic microorganism, Hg-resistant, microorganism density, rhizosphere microorganism

\section{ABSTRAK}

Terdapat sekitar 900 titik pertambangan emas skala kecil (PESK) di Indonesia yang memperoleh emas melalui teknik amalgamasi dan sianidasi. Teknik amalgamasi menyebabkan pencemaran merkuri (Hg) di tanah. Penelitian ini merupakan penelitian pendahuluan (preliminary study) yang bertujuan untuk mengisolasi mikroorganisme endofit dan rhizosfer resisten Hg dari rumput pionir yang tumbuh di tanah yang tercemar Hg. Mikroorganisme paling berpotensi akan diaplikasikan pada fitoremediasi merkuri di penelitian selanjutnya. Sampel rumput pionir diambil dari lahan pertanian bekas kawasan pertambangan emas dengan teknik amalgamasi di Desa Bonjeruk, Kecamatan Jonggat, Kabupaten Lombok Tengah, Nusa Tenggara Barat. Total mikroorganisme dihitung menggunakan Colony Forming Unit (CFU) atau Standard Plate Count. Koloni mikroorganisme dikarakterisasi berdasarkan ciri morfologi. Mikroorganisme endofit dan rizosfer yang resisten $\mathrm{Hg}$ berhasil diisolasi dari rumput pionir (Cynodon dactylon dan Eleusine indica) di lokasi penelitian. Koloni mikroorganisme rizosfer sangat beragam secara morfologi dibandingkan dengan mikroorganisme endofit berdasarkan jumlah mikroorganisme terisolasi, berturut-turut 20 isolat dan 17 isolat. Kepadatan mikroorganisme rizosfer lebih tinggi (96\%) dibandingkan mikroorganisme endofit (4\%). Kepadatan bakteri dan jamur rizosfer masing-masing adalah $47 \times 10^{3}$ dan $2 \times 10^{3} \mathrm{CFU} \mathrm{g}^{-1}$ sedangkan kepadatan bakteri endofit dan jamur masing-masing hanya $2 \times 10^{3}$ dan $1 \times 10^{3} \mathrm{CFU} \mathrm{g}^{-1}$.

Kata kunci: kepadatan mikroorganisme, mikroorganisme endofit, mikroorganisme rizosfer, resisten $\mathrm{Hg}$

\footnotetext{
* Corresponding author. e-mail: reniustiatik@gmail.com
} 


\section{INTRODUCTION}

Indonesia lies in the $7^{\text {th }}$ ranked of gold-producing countries in 2017, with total production is 154.3 tonnes of gold per year ('O'Connell et al., 2018). Indonesia's gold production is supplied by large scale, medium scale, and artisanal and small scale gold mining (ASGM). There are about 900 identified hotspots of ASGM activity in Indonesia and they are found in 32 provinces and 197 cities/ regencies all over Indonesia (BaliFokus Foundation, 2012). Artisanal and small-scale gold mining recovers gold through amalgamation and cyanidation techniques (Handayanto et al., 2014). Amalgamation technique (adding mercury to extract gold from the ore) causes mercury ( $\mathrm{Hg}$ ) pollution; the tailing (solid waste) that contains $\mathrm{Hg}$ might pollute soil and water (Gonçalves et al., 2017).

$\mathrm{Hg}$ pollution in the soil is harmful to humans and the environment (Marrugo-Negrete et al., 2016). Hg in the soil is persistent (Fan et al., 2018). Mercury concentration in the soil of an ASGM, with amalgamation technique, location in Lombok (Sekarbela, near Mataram city) is approximately 741-7,874 mg kg-1 (Krisnayanti et al., 2012). This concentration exceeds the minimum concentration of $\mathrm{Hg}$ in solid waste based on Indonesian Government Regulation (2014), which is $0.3 \mathrm{mg} \mathrm{kg}^{1}$. Also, it exceeds the maximum concentration of $\mathrm{Hg}$ in the soil for agricultural land based on the Canadian Council of Ministers Environment (1999), which is $12 \mathrm{mg} \mathrm{kg}^{-1}$. The high $\mathrm{Hg}$ concentration in the soil is a major limiting factor for plant growth (Hodson, 2012). The primary symptoms of $\mathrm{Hg}$ toxicity in maize are chlorosis (Muddarisna et al., 2013). Plants generally exhibit symptoms of heavy metal toxicity when it is exposed to a high concentration in the soil, except for hyperaccumulator plants that are resistant and able to accumulate heavy metals (Idris et al., 2004).
Some pioneer grass in gold-mine polluted areas such as Digitaria radicosa, Paspalum conjugatum, Cyperus kyllingia, Cynodon dactylon, and Eleusine indica exhibit $\mathrm{Hg}$ resistant (Hidayati et al., 2009; Muddarisna et al., 2013). The ability of plants to survive in heavy metal polluted soil is inseparable from plant association with beneficial microorganisms, either within plant body or rhizosphere niche (Thijs et al., 2017). These microorganisms produce plant growth-promoting substances such as indole acetic acid (IAA) and siderophore that help plants to survive in harsh conditions (Rajkumar et al., 2010; Tirry et al., 2018). Microorganisms that are isolated from heavy metal polluted soil also exhibit heavy metal resistance (Lodewyckx et al., 2002). This study aimed to isolate Hg-resistant endophytic and rhizosphere microorganisms (bacteria and fungi) from pioneer grasses in the abandoned gold mining area.

\section{MATERIALS AND METHODS}

\section{Sampling Site}

Pioneer grasses were collected from the abandoned gold mining area in Bonjeruk Village, Jonggat SubRegency, Central Lombok Regency, West Nusa Tenggara, Indonesia $\left(8^{\circ} 24^{\prime}-8^{\circ} 57^{\prime} \mathrm{S}\right.$ and $116^{\circ} 05^{\prime}-116^{\circ} 24^{\prime} \mathrm{E}$, Figure 1). Grass samples were collected in April 2019. Mercury concentration in the soil was $41.37 \mathrm{mg} \mathrm{kg}^{-1}$ (Ustiatik et al., 2020). Grass samples in the same length size were collected in triplicates (grass length 15-20 cm). Grass species were Cynodon dactylon and Eleusine indica. Soil in the rhizosphere of these grasses was also collected for rhizosphere microorganism isolation. Grass and soil samples were kept in the polyethylene plastics bag and stored in the cooling box for laboratory analysis.

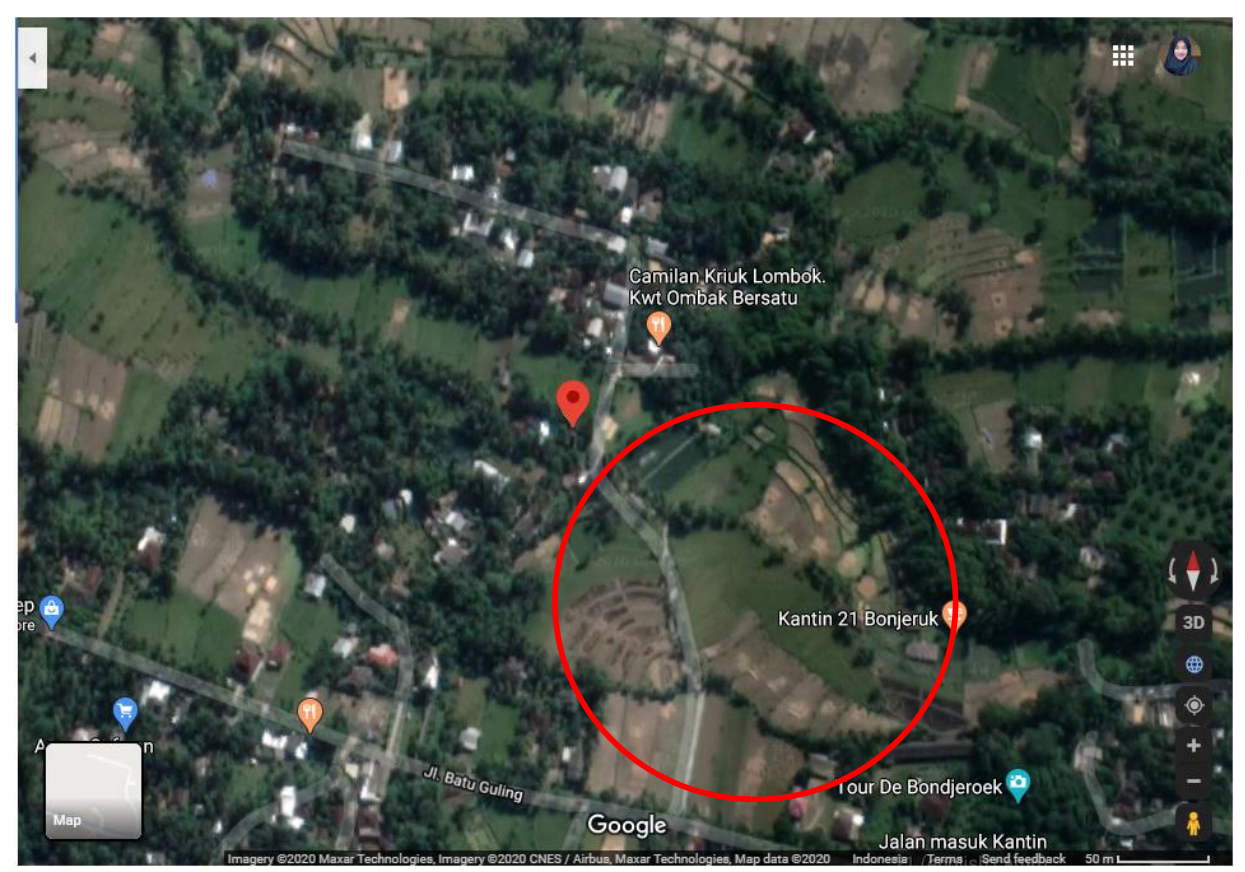

Figure 1. Sampling site of Hg-resistant rhizosphere and endophytic microorganism from local grasses (Cynodon dactylon and Eleusine indica) in abandoned gold mining area, Central Lombok Regency, West Nusa Tenggara 


\section{Endophytic Microorganism Isolation}

Grass samples were washed with running tap water to remove all the debris. Grass samples were surface sterilized with $70 \%$ ethanol for 3 minutes, sodium hypochlorite ( $\mathrm{NaClO}) 2.5 \%$ for 5 minutes, and rinsed several times with sterile deionized water (Xu et al., 2014; Qian et al., 2018). The last rinsed water was cultured in the nutrient agar (OXOID CM0003B) to confirm the success of surface sterilization (Anjum and Chandra, 2015). Five grams of each grass samples were mashed with sterile mortar and pestle in the Laminar Air Flow (LAF). The mashed sample was suspended with $45 \mathrm{~mL}$ of sodium chloride $(\mathrm{NaCl})$ solution $0.86 \%(\mathrm{v} / \mathrm{v})$ and mixed it with Vortex. One milliliter of aliquot was diluted in $9 \mathrm{~mL}$ of $\mathrm{NaCl}$ to make ten folds of serial dilution (up to $10^{-5}$ ). One hundred microliters of aliquot in each serial dilution was cultured in Nutrient Agar (NA) for bacteria isolation and Potato Dextrose Agar (OXOID CM0139B) for fungi isolation. The cultured media were added with $10 \mathrm{mg} \mathrm{L}^{-1}$ of mercury chloride $\left(\mathrm{HgCl}_{2}\right)$ for $\mathrm{Hg}$ resistant microorganism isolation (Xu et al., 2014; Anjum and Chandra, 2015; Chasanah et al., 2018). The inoculated media were incubated at $28{ }^{\circ} \mathrm{C}$ (room temperature) for 48 hours for microorganism enumeration and characterization (Nemati et al., 2016).

\section{Rhizosphere Microorganism Isolation}

Soil rhizosphere samples were cleaned from roots and all debris. Five grams of soil sample were suspended in 45 $\mathrm{mL} \mathrm{NaCl}$ solution $0.86 \%(\mathrm{v} / \mathrm{v})$ then mixed it with Vortex. One milliliter of aliquot was diluted in $9 \mathrm{~mL}$ of $\mathrm{NaCl}$ to make ten folds of serial dilution (up to $10^{-8}$ ). One hundred microliters of aliquot in $10^{-6}, 10^{-7}$, and $10^{-8}$ serial dilution were cultured in NA for bacteria isolation and PDA for fungi isolation. The cultured media were added with $10 \mathrm{mg} / \mathrm{L}$ of $\mathrm{HgCl}_{2}$ for $\mathrm{Hg}$-resistant microorganism isolation (Xu et al., 2014; Anjum and Chandra, 2015; Chasanah et al., 2018). The inoculated media were incubated at room temperature $\left(28^{\circ} \mathrm{C}\right.$ ) for 48 hours for microorganism characterization and enumeration (Nemati et al., 2016).

\section{Microbial Enumeration and Characterization}

Total microorganisms were counted using Colony Forming Unit (CFU) or Standard Plate Count (Nemati et al., 2016). Microorganism colony diversity was characterized based on morphological characteristics such as colony size, form, margin, chromogenesis (pigmentation), elevation, and texture. A colony was determined as a single distinct colony when it was different among other colonies on the same Petri dish.

\section{Data Analysis}

Data were analyzed using One Way ANOVA at 5\% significant level using Genstat software. The relationships among treatment grouping were determined with Tukey's test at 5\% significance level.

\section{RESULTS AND DISCUSSION}

This study successfully isolated Hg-resistant endophytic and rhizosphere microorganisms from pioneer grass (Cynodon dactylon and Eleusine indica) in the study site. These microorganisms survived on media containing $10 \mathrm{mg} \mathrm{L}^{-1} \mathrm{HgCl}_{2}$, which is only Hg-resistant microorganisms that able to survive on those media (Maiti and Bhattacharyya, 2013; Xu et al., 2014; Anjum and Chandra, 2015; Chasanah et al., 2018).

The total colonies of isolated microorganisms were 17 colonies of endophytic microorganisms and 20 colonies of rhizosphere microorganisms (Figure 2). The microorganism was distinguished based on the colonies' morphological characteristics such as colonies' form, size, pigmentation, margin, elevation, and texture. It also showed that endophytic bacteria colonies' appearance was more diverse (Table 1 and Figure 3A) than endophytic fungi (Table 2). However, the rhizosphere fungi colonies were more diverse (Table 3) than the rhizosphere bacteria colonies (Table 4 and Figure 3B). Based on the colony morphological characteristics analysis, there were only two distinct colonies of endophytic fungi (Figure 4A). But, there were eight distinct colonies of rhizosphere fungi (Figure 4B). The colonies of rhizosphere microorganisms were morphologically more diverse than the colonies of endophytic microorganisms. The number of colonies that were isolated implies the diversity of microorganisms. A colony was counted as a single distinct colony when it was different among other colonies on the same growth medium. This study revealed significantly different isolated microorganism densities in the study site (Figure 5). The density of rhizosphere microorganisms in the study site was higher than endophytic microorganisms ( $\mathrm{P}<$ 0.05 ), approximately $96 \%$ of total isolated microorganisms. However, endophytic microorganisms were only $4 \%$ of the total isolated microorganisms. The density of rhizosphere bacteria and fungi were $47 \times 10^{3}$ and $2 \times 10^{3} \mathrm{CFU} \mathrm{g} \mathrm{g}^{-1}$, respectively. However, the density of endophytic bacteria and fungi were $2 \times 10^{3}$ and $1 \times 10^{3} \mathrm{CFU} \mathrm{\textrm {g } ^ { - 1 }}$, respectively. Bacteria (endophytic and rhizosphere) had a higher density than fungi. The density of endophytic microorganisms varies depending on the plant part and species (Elmagzob et

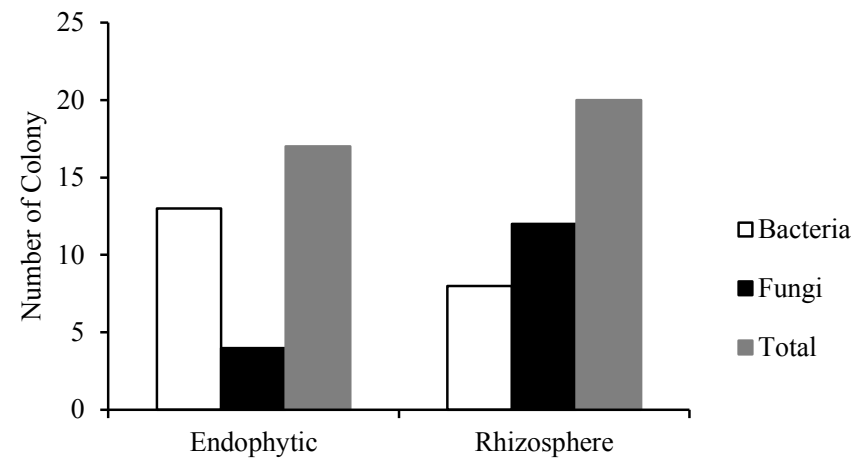

Figure 2. The number of different Hg-resistant microorganism colonies based on colony morphology in the inoculated media (Endophytic bacteria $=13$ isolates; Rhizosphere bacteria $=4$ isolates; Endophytic fungi $=8$ isolates; Rhizosphere fungi $=12$ isolates) 
Table 1. Colony morphology characterization of isolated endophytic bacteria from local grasses

\begin{tabular}{lclllll}
\hline Isolate & \multicolumn{5}{c}{ Colony morphology } \\
\cline { 2 - 6 } code & Size $(\mathrm{mm})$ & Form & Margin & Chromogenesis & Elevation & \multicolumn{1}{c}{ Texture } \\
\hline BA & 6.0 & Circular & Undulate & Cream & Convex & Smooth \\
BB & 11.0 & Circular & Undulate & Orange & Umbonate & Smooth \\
BC & 5.0 & Circular & Undulate & Orange & Convex & Smooth \\
BD & 10.0 & Circular & Entire & Cream & Umbonate & Smooth \\
BE & 8.0 & Circular & Undulate & Cream & Flat & Dry \\
BF & 6.5 & Circular & Lobate & Cream & Umbonate & Rough \\
BG & 13.25 & Irregular & Lobate & Cream & Umbonate & Rough \\
GA & 3.5 & Circular & Lobate & Cream & Flat & Dry \\
GB & 14.0 & Circular & Entire & Cream & Flat & Contain concentric rings \\
GC & 31.5 & Rhizoid & Lobate & Cream & Flat & Dry \\
GD & 14.0 & Circular & Entire & Cream & Flat & Contain concentric rings \\
GE & 14.0 & Circular & Entire & Cream & Flat & Contain concentric rings \\
GF & 31.5 & Rhizoid & Lobate & Cream & Flat & Dry \\
\hline
\end{tabular}

Note: $\mathrm{B}=$ Cynodon dactylon; $\mathrm{G}=$ Eleusine indica

al., 2019). It varies from $4.5 \times 10^{2}$ to $2.8 \times 10^{3} \mathrm{CFU} \mathrm{g}^{-1}$ of fresh weight (Costa et al., 2012). Under stress conditions, the density of microorganisms, either endophytic or rhizosphere, will decrease. The total bioactivity, density, and diversity of microorganisms decreased with the increase of heavy metal concentrations but enhanced the development of metalresistant microbial populations (Xie et al., 2016; Elmagzob et al., 2019).

Mercury concentration in the study site $\left(41.37 \mathrm{mg} \mathrm{kg}^{-1}\right)$ exceeded Hg's permissible concentration in the soil based on Indonesian Government Regulation (2014). It was also exceeded the minimum recommended level for agricultural land (Canadian Council of Ministers Environment, 1999; Ustiatik et al., 2020). Hg concentration in the previous study by Ustiatik et al. (2020) was 17 times lower than the study by Krisnayanti et al. (2012). After eight years, Hg concentration in the abandoned gold mining area decreased. This location is currently used as agricultural land and fish ponds. Some grass species vegetated in this area, such as Cynodon dactylon and Eleusine indica. These grasses were pioneer vegetation in the study site.

Plants' ability to grow in polluted areas cannot be separated from beneficial microorganisms and plants' interaction. These microorganisms reside within the plant's body or in the rhizosphere (Thijs et al., 2017). These microorganisms help plants survive in heavy metal stress conditions by producing plant growth hormones such as IAA, siderophore production, and nitrogen fixation (Rajkumar et al., 2009; Montalban et al., 2016).



Figure 3. Endophytic bacteria colonies (A) and rhizosphere bacteria colonies (B) 
Table 2. Colony morphology characterization of isolated endophytic fungi from local grasses

\begin{tabular}{|c|c|c|c|c|c|c|}
\hline \multirow{3}{*}{$\begin{array}{l}\text { Isolate } \\
\text { code }\end{array}$} & \multicolumn{5}{|c|}{ Colony characteristics } & \multirow{3}{*}{ Elevation } \\
\hline & \multirow{2}{*}{ Size $(\mathrm{mm})$} & \multirow{2}{*}{ Form } & \multirow{2}{*}{ Margin } & \multicolumn{2}{|c|}{ Pigmentation } & \\
\hline & & & & Front & Back & \\
\hline B1 & 47.75 & Filamentous & Lobate & Black-greenish & $\begin{array}{l}\text { Grey (center) White } \\
\text { (margin) }\end{array}$ & Raised \\
\hline B2 & 48.00 & Irregular & Undulate & $\begin{array}{l}\text { White (margin) Goldish- } \\
\text { yellow (center) }\end{array}$ & $\begin{array}{l}\text { White-yellowish (margin) } \\
\text { Goldish-yellow (center) }\end{array}$ & Raised \\
\hline G1 & 4.25 & Rhizoid & Lobate & White & White-yellowish & Umbonate \\
\hline $\mathrm{G} 2$ & 4.25 & Rhizoid & Lobate & White & White-yellowish & Umbonate \\
\hline
\end{tabular}

Note: $\mathrm{B}=$ Cynodon dactylon; $\mathrm{G}=$ Eleusine indica

Table 3. Colony morphology characterization of isolated rhizosphere bacteria from the rootzone of local grasses

\begin{tabular}{lclllll}
\hline \multirow{2}{*}{ Isolate } & \multicolumn{5}{c}{ Colony morphology } \\
\cline { 2 - 6 } & Size $(\mathrm{mm})$ & Form & Margin & Chromogenesis & Elevation & \multicolumn{1}{c}{ Texture } \\
\hline RHI A & 10.5 & Circular & Entire & Yellow & Raised & Contain concentric rings radial \\
RHI B & 6.0 & Circular & Entire & Cream & Raised & Smooth and shiny \\
RHI C & 13.25 & Rhizoid & Lobate & Cream & Crateriform & Contain concentric rings \\
RHI D & 1.5 & Circular & Entire & Yellowish & Convex & Shiny \\
RHI E & 11.0 & Circular & Lobate & Cream & Umbonate & Smooth and shiny \\
RHI F & 14.0 & Irregular & Lobate & Cream & Raised & Contain concentric rings \\
RHI G & 5.5 & Irregular & Entire & Cream & Flat & Dry \\
RHI H & 3.5 & Irregular & Entire & Yellowish & Umbonate & Smooth and shiny \\
\hline
\end{tabular}

Table 4. Colony morphology characterization of isolated rhizosphere fungi from the rootzone of local grasses

\begin{tabular}{lrlllll}
\hline & \multicolumn{5}{c}{ Colony morphology } \\
\cline { 2 - 5 } Isolate & $\begin{array}{c}\text { Size } \\
(\mathrm{mm})\end{array}$ & Form & Margin & \multicolumn{2}{c}{ Pigmentation } & Elevation \\
\cline { 4 - 5 } RHI 1 & 32.5 & Irregular & Undulate & Yellow & Yellow & Raised \\
RHI 2 & 40.0 & Rhizoid & Filamentous & Gray & Black & Flat \\
RHI 3 & 33.0 & Circular & Filamentous & Gray & White-pinkish & Flat \\
RHI 4 & 18.0 & Irregular & Filamentous & White & White-yellowish & Flat \\
RHI 5 & 42.5 & Irregular & Lobate & White-Yellowish & White-yellowish & Umbonate \\
RHI 6 & 15.0 & Circular & Lobate & White & White-brownish & Umbonate \\
RHI 7 & 20.0 & Circular & Undulate & Green & Green-brownish & Umbonate \\
RHI 8 & 19.0 & Circular & Entire & Green & Black & Raised \\
RHI 9 & 8.5 & Circular & Filamentous & White & Brown & Umbonate \\
RHI 10 & 9.5 & Circular & Lobate & White & White-yellowish & Crateriform \\
RHI 11 & 52.0 & Circular & Undulate & Pink-goldish & White-brownish & Crateriform \\
RHI 12 & 35.5 & Circular & Filamentous & Green-whitish & Green-blackish & Umbonate \\
\hline
\end{tabular}




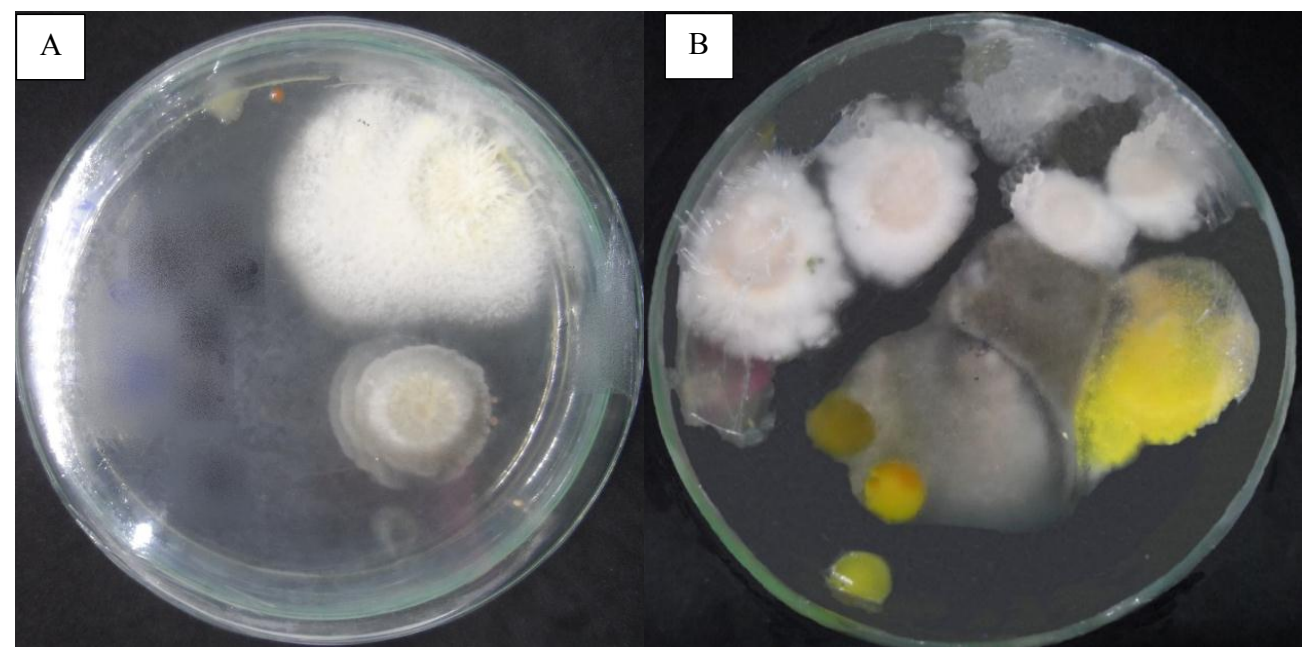

Figure 4. Endophytic fungi colonies (A) and rhizosphere fungi colonies (B)

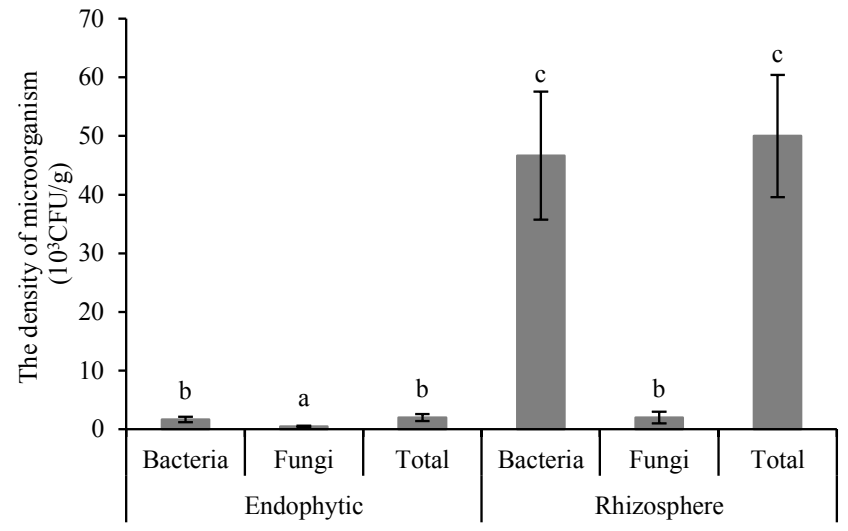

Figure 5. The mean ( \pm standard deviation) of density of $\mathrm{Hg}$ resistant microorganisms in the study site. The means with the same letter are not significantly different $(\mathrm{P}>$ 0.05 ) as determined by Tukey's test

\section{CONCLUSION}

The colonies of rhizosphere microorganisms were morphologically more diverse than the colonies of endophytic microorganisms. The density of rhizosphere microorganisms in the study site was higher than endophytic microorganisms. The density of rhizosphere bacteria and fungi were $47 \times 10^{3}$ and $2 \times 10^{3} \mathrm{CFU} \mathrm{g}^{-1}$, respectively. However, the density of endophytic bacteria and fungi were only $2 \times 10^{3}$ and $1 \times 10^{3} \mathrm{CFU} \mathrm{g}^{-1}$, respectively.

\section{ACKNOWLEDGEMENT}

This research was funded by the Ministry of Research, Technology, and Higher Education of Indonesia (KEMENRISTEK DIKTI), especially for the Master and Ph.D. Scholarship (Beasiswa PMDSU). The authors thank field and laboratory assistant and Bonjeruk Farmers
Association of Central Lombok, West Nusa Tenggara, Indonesia, for the support (Pak Jemur and Pak Amrullah).

\section{REFERENCES}

Anjum, N., R. Chandra. 2015. Endophytic Bacteria: Optimizaton of isolation procedure from various medicinal plants and their preliminary characterization. Asian J. Pharmaceutical Clin. Res. 8:233-238.

BaliFokus Foundation. 2012. Inventory of mercury releases in Indonesia. BaliFokus foundation. https://www. balifokus.asia [11 March 2020].

Canadian Council of Ministers of the Environment. 1999. Canadian Soil Quality Guidelines for the Protection of Environmental and Human Health. CanadaEnvironmental Quality Guidelines No 6. https:// www.esdat.net [11 March 2020].

Chasanah, U., Y. Nuraini, E. Handayanto. 2018. The potential of mercury-resistant bacteria isolated from small-scale gold mine tailings for accumulation of mercury. J. Ecol. Engineering 19:238-247.

Costa, L.E.O., M.V.Q.A.C. Borges, C.A. de Moraes, E.F. de Araújo. 2012. Isolation and characterization of endophytic bacteria isolated from the leaves of the common bean (Phaseolus vulgaris). Brazilian J. Microbiol. 15:62-75.

Elmagzob, A.A.H., M.M. Ibrahim, G.F. Zhang. 2019. Seasonal diversity of endophytic bacteria associated with Cinnamomum camphora (L.) Presl. Diversity. 11:112. 
Fan, M., Z. Liu, L. Nan, E. Wang, W. Chen, Y. Lin, G. Wei. 2018. Isolation, characterization, and selection of heavy metal-resistant and plant growth-promoting endophytic bacteria from root nodules of Robinia pseudoacacia in a $\mathrm{Pb} / \mathrm{Zn}$ mining area. Microbiol. Res. 217:51-59.

Gonçalves, A.O., B.G. Marshall, R.J. Kaplan, J. MorenoChavez, M.M. Veiga. 2017. Evidence of reduced mercury loss and increased use of cyanidation at gold processing centers in southern Ecuador. J. Cleaner Production. 165:836-45.

Handayanto, E., N. Muddarisna, B.D. Krisnayanti. 2014. The potential of local trees for phytostabilization of heavy metals in gold cyanidation tailing contaminated soils of west Lombok, Indonesia. Amer-Eur. J. Sust. Agric. 8:15-21.

Hidayati, N., T. Juhaeti, F. Syarif. 2009. Mercury and cyanide contaminations in gold mine environment and possible solution of cleaning up by using phytoextraction. HAYATI Journal of Biosciences. 16:88-94.

Hodson, M. J. 2012. Metal toxicity and tolerance in plants. Biochemist 34:28-32.

Idris, R., R. Trifonova, M. Puschenreiter, W.W. Wenzel, A. Sessitsch. 2004. Bacterial communities associated with flowering plants of the Ni hyperaccumulator Thlaspi goesingense. Appl. Environ. Microbiol. 70:2667-77.

Indonesia Government Regulation. 2014. Indonesia Government Regulation No. 101 about Management of hazardous and toxic wastes (Peraturan Pemerintah Nomor 101 Tahun 2014 tentang Pengelolaan Limbah Bahan Berbahaya dan Beracun). https://peraturan. bpk.go.id [11 March 2020].

Krisnayanti, B.D., C.W.N. Anderson, W.H. Utomo, X. Feng, E. Handayanto, N. Mudarisna, H. Ikram, Khususiah. 2012. Assessment of environmental mercury discharge at a four-year-old artisanal gold mining area on Lombok Island, Indonesia. J. Environ. Monit. 14:2598-2607.

Lodewyckx, C., M. Mergeay, J. Vangronsveld, H. Clijsters, D. Van der Lelie. 2002. Isolation, characterization, and identification of bacteria associated with the zinc hyperaccumulator Thlaspi caerulescens subsp. Calaminaria. Int. J. Phytoremediation 4:101-15.
Maiti, A., S. Bhattacharyya. 2013. Isolation and characterization of mercury resistant bacteria from Haldia river sediments. IOSR J. Environ. Sci. Toxicol. Food Technol. 5:23-28.

Marrugo-Negrete, J., J.D. Hernández1, J.P. Hernández, G.E. Montes, S. Díez. 2016. Mercury uptake and effects on growth in Jatropha curcas. J. Environ. Sci. 48:120-125.

Montalbán, B., S. Croes, N. Weyens, M.C. Lobo, A. PérezSanz, J. Vangronsveld. 2016. Characterization of bacterial communities associated with [Brassica napus L.] growing on a $\mathrm{Zn}$-contaminated soil and their effects on root growth. Int. J. Phytoremediation 18:985-993.

Muddarisna, N., B.D. Krisnayanti, S.R. Utami. 2013. The potential of wild plants for phytoremediation of soil contaminated with mercury of gold cyanidation tailings. IOSR J. Environ. Sci. Toxicol. Food Technol. $4: 15-19$.

Nemati, M., A. Hamidi, S.M. Dizaj, V. Javaherzadeh, F. Lotfipour. 2016. An overview on novel microbial determination methods in pharmaceutical and food quality control. Adv. Pharm Bull. 6:301-308.

O’Connell, R., C. Alexander, R. Strachan, B. Always, S. Nambiath, J. Wiebe, S. Li, N. Scott-Gray, D. Aranda, Z. Chan. 2018. GFMS Gold Survey 2018. Thomson Reuters. http://images.financial-risk-solutions. [11 March 2020].

Qian, X., Y. Wu, H. Zhou, X. Xu, Z. Xu, L. Shang, G. Qiu. 2018. Total mercury and methylmercury accumulation in wild plants grown at wastelands composed of mine tailings: Insights into potential candidates for phytoremediation. Environ. Pollut. 239:757-67.

Rajkumar, M., N. Ae, H. Freitas. 2009. Endophytic bacteria and their potential to enhance heavy metal phytoextraction. Chemosphere 77:153-60.

Rajkumar, M., N. Ae, M.N.V. Prasad, H. Freitas. 2010. Potential of siderophore-producing bacteria for improving heavy metal phytoextraction. Trends in Biotechnol. 28:142-49.

Thijs, S., W. Sillen, N. Weyens, J. Vangronsveld. 2017. Phytoremediation: State-of-the-art and a key role for the plant microbiome in future trends and research prospects. Int. J. Phytoremediation 19:23-38. 
Tirry, N., N.T. Joutey, H. Sayel, A. Kouchou, W. Bahafid, M. Asri, N. El Ghachtouli. 2018. Screening of plant growth promoting traits in heavy metals resistant bacteria: prospects in phytoremediation. J. Genet. Eng. Biotechnol. 16:613-19.

Ustiatik, R., S. Nurfitriani, A. Fiqri, E. Handayanto. 2020. The use of mercury-resistant bacteria to enhance phytoremediation of soil contaminated with smallscale gold mine tailing. Nat. Environ. Pollut. Technol. 19:53-61.
Xie, Y., J. Fan, W. Zhu, E. Amombo, Y. Lou, L. Chen, J. Fu. 2016. Effect of heavy metals pollution on soil microbial diversity and bermudagrass genetic variation. Front. Plant Sci. 7:1-12.

Xu, J., A.G. Bravo, A. Lagerkvist, S. Bertilsson, R. Sjöblomb, J. Kumpiene. 2014. Sources and remediation techniques for mercury contaminated soil. Environ. Int. 74:42-53. 